\title{
Comparative evaluation of $\mathrm{N}$-acetylcysteine and $\mathrm{N}$-acetylcysteineamide in acetaminophen-induced hepatotoxicity in human hepatoma HepaRG cells
}

\author{
Shakila Tobwala, Ahdab Khayyat, Weili Fan and Nuran Ercal \\ Department of Chemistry, Missouri University of Science and Technology, Rolla, MO 65409, USA \\ Corresponding author: Nuran Ercal. Email: nercal@mst.edu
}

\begin{abstract}
Acetaminophen ( $\mathrm{N}$-acetyl-p-aminophenol, APAP) is one of the most widely used over-the-counter antipyretic analgesic medications. Despite being safe at therapeutic doses, an accidental or intentional overdose can result in severe hepatotoxicity; a leading cause of drug-induced liver failure in the U.S. Depletion of glutathione (GSH) is implicated as an initiating event in APAP-induced toxicity. N-acetylcysteine (NAC), a GSH precursor, is the only currently approved antidote for an APAP overdose. Unfortunately, fairly high doses and longer treatment times are required due to its poor bioavailability. In addition, oral and intravenous administration of NAC in a hospital setting are laborious and costly. Therefore, we studied the protective effects of N-acetylcysteineamide (NACA), a novel antioxidant, with higher bioavailability and compared it with NAC in APAP-induced hepatotoxicity in a human-relevant in vitro system, HepaRG. Our results indicated that exposure of HepaRG cells to APAP resulted in GSH depletion, reactive oxygen species (ROS) formation, increased lipid peroxidation, mitochondrial dysfunction (assessed by JC-1 fluorescence), and lactate dehydrogenase release. Both NAC and NACA protected against APAP-induced hepatotoxicity by restoring GSH levels, scavenging ROS, inhibiting lipid peroxidation, and preserving mitochondrial membrane potential. However, NACA was better than NAC at combating oxidative stress and protecting against APAP-induced damage. The higher efficiency of NACA in protecting cells against APAP-induced toxicity suggests that NACA can be developed into a promising therapeutic option for treatment of an APAP overdose.
\end{abstract}

Keywords: Glutathione-prodrug, oxidative stress, N-acetyl-p-benzoquinoneimine, mitochondria, glutathione

Experimental Biology and Medicine 2015; 240: 261-272. DOI: 10.1177/1535370214549520

\section{Introduction}

Overdose of acetaminophen (APAP), an effective antipyretic/analgesic medication, is a common cause of acute liver failure in the U.S. ${ }^{1-4}$ Overdoses of APAP account for nearly 50-80,000 hospital emergency visits and about 500 deaths each year in the U.S., ${ }^{5,6}$ At therapeutic doses, more than $90 \%$ of the APAP is glucuronidated or sulfated in the liver and then excreted; ${ }^{78}$ however, about $4-5 \%$ is metabolized by cytochrome P450 enzymes (CYP450) (including CYP1A2, CYP3A4, and mainly CYP2E1) to the electrophilic intermediate N-acetyl-p-benzoquinoneimine (NAPQI). ${ }^{7,9}$ This intermediate is highly reactive and is eliminated by conjugation with glutathione (GSH) to directly form 3 -(glutathione-S-yl) acetaminophen, 7,10 or catalyzed by glutathione S-transferase, which is excreted in urine. However, after an overdose of APAP, the formation of NAPQI exceeds the detoxification capacity of GSH so that it arylates essential nucleophilic macromolecules within the hepatocytes, forming stable APAP protein adducts. ${ }^{11,12}$ This represents an initial and irreversible step in the development of APAP-induced hepatotoxicity. ${ }^{11}$ Since the detoxification of NAPQI by GSH is extremely rapid $\left(\mathrm{k}_{1}=3.2 \times 10^{4} \mathrm{M} / \mathrm{s}\right.$ at $\left.\mathrm{pH} 7.0\right){ }^{13}$ covalent binding of NAPQI to proteins would occur only after more than $70 \%$ of the GSH is depleted. ${ }^{14}$

NAPQI binds more frequently to mitochondrial protein ${ }^{15,16}$ that leads to mitochondrial membrane permeability transition (MPT). This is characterized by mitochondrial swelling, uncoupling of oxidative phosphorylation, and formation of pores in the mitochondrial membrane. ${ }^{17}$ Consequently, the apoptosis-inducing factor and endonuclease $G$ are released from the mitochondria and are translocated to the nucleus, resulting in fragmentation of DNA. ${ }^{17}$ Collapse of the mitochondrial membrane potential, together with extensive DNA damage, contributes to 
necrosis of the hepatocytes. This is supported by studies which report that the prevention of MPT protected against APAP-induced damage. ${ }^{18-20}$ Furthermore, the exposure of mouse hepatocytes to NAPQI stimulated the mitochondrial dysfunction that was observed with APAP. ${ }^{21}$

Uncoupling of cytochrome P-450 2E1 appears to be a significant mechanism that leads to increased reactive oxygen species (ROS) in APAP toxicity. The superoxide anion, thus formed, dismutates to hydrogen peroxide ${ }^{22}$ and eventually forms highly reactive hydroxyl radicals which may, in turn, oxidize lipids that lead to initiation of lipid peroxidation as well as oxidation of proteins and nucleic acids. In addition, GSH peroxidase, a major peroxide detoxification enzyme, is stalled due to the lack of its substrate, GSH. Thus, depletion of GSH, which is crucial for maintaining a cellular redox state, results in acute oxidative stress.

Since GSH depletion by excessive NAPQI is a critical event in APAP-induced hepatotoxicity, ${ }^{23,24} \mathrm{~N}$ acetylcysteine (NAC), a GSH precursor that has been used to treat patients with APAP-induced toxicity, ${ }^{25-27}$ is the only approved antidote for treatment of APAP-induced hepatotoxicity. NAC functions to restore GSH levels, the body's natural defense against endogenously generated ROS and NAPQI, by providing an important GSH precursor, cysteine, via deacetylation. ${ }^{28,29}$ Furthermore, treatment with excess NAC after APAP supplies mitochondrial energy substrates in the Krebs cycle and restores hepatic ATP levels. ${ }^{30}$ Unfortunately, NAC is negatively charged at physiological $\mathrm{pH}$, limiting its ability to cross cell membranes and, therefore, requires higher doses and longer treatment times. However, in NACA, a novel GSH-prodrug, the carboxyl group is replaced with an amide which increases its lipophilicity, allowing it to cross cell membranes.

NACA is an excellent source of sulfhydryl (-SH) groups that can be converted by the cells into metabolites capable of stimulating GSH synthesis. The molecule can also promote intracellular detoxification and act directly as a free radical scavenger. Previous studies have shown that NACA is lipophilic and can cross membranes, chelate $\mathrm{Cu}^{2+}$ (which catalyzes free radical formation), scavenge free-radicals, and protect against oxidative stress. ${ }^{31-40}$ In addition, the nausea and vomiting, caused when NAC is administered orally, and the anaphylactic reactions that follow its intravenous administration, ${ }^{41,42}$ could be overcome by using a lower dose of NACA, which has higher bioavailability. Promising results with NACA in various oxidative stress-related disorders encouraged us to investigate the ability of NACA to protect against APAPinduced toxicity.

Therefore, the present study was undertaken to evaluate the therapeutic efficiency of NACA in APAP-induced toxicity. In addition, we used HepaRG, a human hepatoma cell line which expresses phases I and II drug metabolizing enzymes, membrane transporters, the GSH-related enzymes, and thioredoxin. Activities of phase I and II enzymes of this cell line were comparable to freshly isolated human hepatocytes. ${ }^{43,44}$ Previous studies have used HepG2, which is not an ideal model for studying drug metabolism and toxicity. HepG2 cells do not express phase I enzymes ${ }^{45}$ and, therefore, cannot form the reactive metabolite, NAPQI, which initiates hepatotoxicity by depleting GSH and protein adduct formation. Moreover, the therapeutic efficiency of NACA was compared with NAC in APAP-induced toxicity in HepaRG cells.

Our data showed that NACA protects against APAPinduced toxicity by de novo synthesis of intracellular GSH, scavenging ROS, inhibiting lipid peroxidation, and preserving mitochondrial membrane potential. NACA is significantly better than NAC and can potentially be developed into a promising therapeutic option for patients undergoing therapy after an APAP overdose and also in hepatotoxicity resulting from long-term APAP use. The enhanced ability to penetrate cells allows NACA to be administered at a lower dose than NAC, giving the drug a greater therapeutic index and lowering the risk of side effects that traditionally have been associated with higher doses of NAC. ${ }^{34}$

\section{Materials and methods Materials}

The human hepatoma cells (HepaRG) were obtained from Invitrogen. NACA was gifted by Dr Glenn Goldstein (David Pharmaceuticals, New York, NY). N-(1-pyrenyl)maleimide (NPM) was obtained from Sigma-Aldrich (St. Louis, MO). High performance liquid chromatography (HPLC) grade solvents were purchased from Fisher Scientific (Fair Lawn, NJ). All other chemicals were bought from Sigma-Aldrich (St. Louis, MO).

\section{Culture of human hepatoma cells, HepaRG, and experimental design for oxidative stress parameters}

The human hepatoma cells (HepaRG) were seeded in $75 \mathrm{~cm}^{2}$ tissue culture flasks coated with type 1 rat tail collagen (Sigma-Aldrich, St. Louis, MO). They were maintained in William's E medium supplemented with $10 \%$ fetal calf serum, $100 \mathrm{U}$ penicillin, $100 \mu \mathrm{g} / \mathrm{mL}$ streptomycin, $5 \mu \mathrm{g} / \mathrm{mL}$ insulin, and hydrocortisone in humidified $5 \% \mathrm{CO}_{2} / 95 \%$ air at $37^{\circ} \mathrm{C}$. The culture medium was renewed every 3 days. After about 2 weeks, when the flask was full, the cells were shifted to the same medium supplemented with $2 \%$ dimethyl sulfoxide (DMSO) (differentiation medium). The medium was renewed every 2-3 days for 2 more weeks. After that, the medium was switched to a DMSO-free medium for 1 day, and the cells were ready for experiments.

For dosing cells with APAP, NAC, and NACA, we used serum-free and growth-factor-free medium for all experiments, instead of the fully supplemented media described earlier. To assess the cytotoxicity of NAC/NACA, the HepaRG cells were incubated with different concentrations of NAC/NACA, ranging from 0.1 to $10 \mathrm{mM}$. NAC/NACA did not affect cell viability at concentrations lower than $500 \mu \mathrm{M}$. Cells were also incubated with different concentrations of APAP, ranging from 5 to $50 \mathrm{mM}$, to study its effect on cell viability. The cell viability decreased to approximately $60 \%$ of the control when treated with $20 \mathrm{mM}$ of APAP and, therefore, this concentration of APAP was determined to be optimal for further studies. When cells were 
pretreated with different concentrations of NAC/NACA, followed by treatment with $20 \mathrm{mM}$ of APAP, the optimum NAC/NACA dose that provided maximum protection was $250 \mu \mathrm{M}$ NACA and, therefore, we chose to use $250 \mu \mathrm{M}$ NAC/NACA for all other studies. Oxidative stress parameters, including GSH, MDA, and glutathione reductase (GR) activities were measured after the cells had been treated, as described here. After seeding the cells, the flasks were divided into the following six groups: (1) control, (2) NAC only, (3) NACA only, (4) APAP only, (5) $\mathrm{APAP}+\mathrm{NAC}$, and (6) APAP + NACA. In groups pretreated with NAC/NACA, a media containing $250 \mu \mathrm{M}$ of NAC/ NACA were added and incubated for $2 \mathrm{~h}$. After pretreatment, the media in the control, NAC only, and NACA-only groups were replaced with plain media, while the remaining three groups received media containing APAP for either 12 or $24 \mathrm{~h}$. The cell pellets obtained were then further processed for appropriate assays. All assays were performed at least in triplicate.

\section{Determination of cell viability}

The HepaRG cells were seeded in a 96-well tissue culture plate, at a density of approximately $1.0 \times 10^{4}$ cells/well, for a day. The medium was then discarded. The protective effects of NAC/NACA were studied by preincubating cells with $250 \mu \mathrm{M}$ of NAC/NACA for $2 \mathrm{~h}$, followed by treatment with $20 \mathrm{mM}$ of APAP for $24 \mathrm{~h}$ in serum-free medium. After $24 \mathrm{~h}$ of APAP treatment, the medium was discarded and a Calcein AM assay KIT (Biotium, Inc. CA) was used to determine cell viability relative to the control group. The cells were washed three times with Phosphate buffered saline (PBS), and $100 \mu \mathrm{L}$ of $2.0 \mu \mathrm{M}$ Calcein AM in PBS were added to each well for $30 \mathrm{~min}$ at $37^{\circ} \mathrm{C}$. The fluorescence was measured with an excitation wavelength at $485 \mathrm{~nm}$ and an emission wavelength of $530 \mathrm{~nm}$, using a microplate reader (FLUOstar, BMG Labtechnologies, Durham, NC, USA). To further assess the role of NAPQI (a putative toxic metabolite of APAP) on cell viability, cells were pretreated with NAC/NACA, as described earlier, followed by incubation with $250 \mu \mathrm{M}$ of NAPQI (dissolved in $0.1 \% \mathrm{DMSO}$ ) for $24 \mathrm{~h}$. The media in the control groups also had $0.1 \%$ DMSO. After $24 \mathrm{~h}$ of APAP treatment, the medium was discarded and a Calcein AM assay KIT (Biotium, Inc. CA) was used to determine cell viability relative to the control group.

\section{Lactate dehydrogenase release assay}

Lactate dehydrogenase (LDH) measurement in the media determines the membrane integrity. HepaRG cells were seeded in the 96-well plate at a density of approximately $1 \times 10^{4}$ cell/well and incubated with APAP for $24 \mathrm{~h}$ after appropriate pretreatment with NAC/NACA. We used the LDH assay kit (Promega), which quantitatively measures LDH, a stable cytosolic enzyme that is released upon cell lysis. The LDH that was released into the cultured medium was measured within $30 \mathrm{~min}$ by the coupled enzymatic assay.

\section{Determination of intracellular GSH}

Intracellular GSH content was determined by reverse phase HPLC, according to the method developed in our laboratory. ${ }^{46}$ HepaRG cell samples were homogenized in serine borate buffer (SBB). Fifty microliters of this homogenate were added to $200 \mu \mathrm{L}$ of HPLC grade water and $750 \mu \mathrm{L}$ of NPM (1 mM in acetonitrile). The resulting solutions were incubated at room temperature for $5 \mathrm{~min}$. The reaction was stopped by adding $10 \mu \mathrm{L}$ of $2 \mathrm{~N} \mathrm{HCl}$. The samples were then filtered through a $0.45 \mu \mathrm{m}$ filter (Advantec MFS, Inc. Dulin, CA, USA) and injected onto the HPLC system. A total of $5 \mu \mathrm{L}$ of the sample was injected for analysis using a Thermo Finnigan TM Spectra SYSTEM SCM1000 Vacuum Membrane Degasser, Finnigan TM SpectraSYSTEM P2000 Gradient Pump, Finnigan TM SpectraSYSTEM AS3000 Autosampler, and FinniganTM SpectraSYSTEM FL3000 Fluorescence Detector $(\lambda \mathrm{ex}=330 \mathrm{~nm}$ and $\lambda \mathrm{em}=376 \mathrm{~nm})$. The HPLC column was a Reliasil ODS-1 C18 column (Column Engineering, Ontario, CA, USA). The mobile phase was $70 \%$ acetonitrile and $30 \%$ water and was adjusted to a $\mathrm{pH}$ of 2.5 through the addition of $1 \mathrm{ml} / \mathrm{L}$ of both acetic and o-phosphoric acids. The NPM derivatives were eluted from the column isocratically at a flow rate of $1 \mathrm{~mL} / \mathrm{min}$.

\section{Determination of total glutathione and glutathione disulfide (GSSG)}

Total glutathione content was determined by reverse phase HPLC. HepaRG cells were homogenized in SBB. Twenty microliters of this homogenate were added to $60 \mu \mathrm{L}$ of NADPH $(2 \mathrm{mg} / \mathrm{mL})$ in nanopure water and $20 \mu \mathrm{L}$ of $1 \mathrm{unit} / \mathrm{mL}$ glutathione reductase were added to reduce GSSG. After $3 \mathrm{~min}$ of incubation at room temperature, the treated samples were diluted with $150 \mu \mathrm{L} \mathrm{H}_{2} \mathrm{O}$, and then immediately derivatized with $750 \mu \mathrm{L}$ of $1.0 \mathrm{mM}$ NPM. These samples were analyzed as detailed for the determination of GSH using reverse phase HPLC. Data from the original GSH levels and the total GSH levels in each sample were subsequently used to calculate the levels of GSSG present in each sample.

\section{Intracellular ROS measurement}

Intracellular ROS generation was measured using a wellcharacterized probe, 2', $7^{\prime}$-dichlorofluorescin diacetate (DCFH-DA) ${ }^{47}$ HepaRG cells were seeded at a density of $1.25 \times 10^{4}$ cells/well in a 96-well plate for a day. DCFHDA was hydrolyzed by esterases to dichlorofluorescin (DCFH), which is trapped within the cell. This nonfluorescent molecule is then oxidized to fluorescent DCFH by the action of cellular oxidants. The cells were incubated with a solution of $40 \mu \mathrm{M}$ DCFH-DA in phenol red free media for $1 \mathrm{~h}$. This was followed by washing the cells twice with PBS. In the groups with NAC/NACA pretreatment, media containing $250 \mu \mathrm{M}$ of NAC/NACA was added and incubated for $2 \mathrm{~h}$. Once pretreated, the cells were washed twice with PBS and treated with $20 \mathrm{mM}$ of APAP for $12 \mathrm{~h}$. The fluorescence was determined at $485 \mathrm{~nm}$ excitation and $520 \mathrm{~nm}$ emission, using a microplate reader (FLUOstar, BMG Labtechnologies, Durham, NC, USA). 


\section{Lipid peroxidation measurement}

Malondialdehyde (MDA) is a thiobarbituric acid reactive substance. The extent of lipid peroxidation was determined as described by Shi et al. ${ }^{48}$ Briefly, the cell pellets were homogenized in SBB. To $0.350 \mathrm{~mL}$ of cell homogenate, $0.550 \mathrm{~mL}$ of $5 \%$ trichloroacetic acid and $0.100 \mathrm{~mL}$ of $500 \mathrm{ppm}$ butylated hydroxytoluene in methanol were added. The samples were then heated in a boiling water bath for $30 \mathrm{~min}$. After cooling on ice, the samples were centrifuged. The supernatant fractions were mixed 1:1 with saturated thiobarbituric acid (TBA). The samples were again heated in a boiling water bath for $30 \mathrm{~min}$. After cooling on ice, $0.50 \mathrm{~mL}$ of each sample was extracted with $1 \mathrm{~mL}$ of n-butanol and centrifuged to facilitate the separation phases. The resulting organic layers were first filtered through a $0.45 \mu \mathrm{m}$ filter and transferred to a 96-well plate for analysis. Fluorescence was then measured (ex. $510 \mathrm{~nm}$ and em. $590 \mathrm{~nm}$ ).

\section{Determination of glutathione reductase (GR) activity}

GR is the enzyme responsible for recycling GSSG into GSH via a reduction mechanism, utilizing both GSSG and NADPH as a substrate. The activity of this enzyme was determined using a commercial kit from OxisResearch (Portland, OR, USA). The oxidation of NADPH to $\mathrm{NADP}^{+}$was accompanied by a decrease in absorbance at $340 \mathrm{~nm}$, providing a spectrophotometric means for monitoring the enzyme activity of GR. The activity of GR in cells was determined by adding homogenate to a solution containing both GSSG and NADPH and then recording the absorbance as a function of time at $340 \mathrm{~nm}$. The rate of decrease in the A340 was directly proportional to the GR activity in the sample.

\section{Measurement of mitochondrial membrane potential $(\Delta \Psi \mathrm{m})$}

Mitochondrial membrane potential was determined using the potentiometric fluorescent dye JC-1 (Invitrogen). HepaRG cells were cultured in glass-bottom petri dishes and were treated with NAC/NACA and APAP as described earlier. The cells were washed twice with PBS and then incubated with JC-1 dye $(1 \mu \mathrm{g} / 1 \mathrm{~mL})$ in a medium for $30 \mathrm{~min}$. The cells were then washed and placed under a fluorescence microscope in a phenolred-free medium. The stained cells were observed with an Olympus IX51 inverted microscope at $400 \times$ total magnification with a UPLFLN $60 \times$ NA 1.25 objective. FITC (ex 482/35 506DMem 536/40) and Texas red (ex 562/40 593DMem692/40) filters were used (Brightline). Images were captured with a Hamamatsu ORCA285 CCD camera. The shutters, filters, and camera were controlled using Slide Book software (Intelligent Imaging Innovations, Denver, CO, USA).

\section{Determination of protein}

Protein levels of the cell samples were measured by the Bradford method. ${ }^{49}$ Bovine serum albumin was used as the protein standard.

\section{Statistical analysis}

All reported values were represented as the mean \pm standard deviation $(n=3-5)$. Statistical analysis was performed using the GraphPad Prism software (GraphPad, San Diego, CA). Statistical significance was ascertained by one-way as well as two-way analysis of variance, followed by Tukey's multiple comparison tests. Values of $p<0.05$ were considered significant.

\section{Results}

\section{Effect of APAP and NAC/NACA on HepaRG cell viability}

A dose- and time-dependent decrease in cell viability was observed in HepaRG cells upon exposure to APAP (Figure 1(a) and (b)), which was confirmed using a Calcein AM assay. Based on the dose-response relationship, a $20 \mathrm{mM}$ concentration of APAP, which decreased cell viability by about $40 \%$ in $24 \mathrm{~h}$, was determined to be optimal for evaluating the protective effects of NAC/NACA. It is interesting that cell viability at $24 \mathrm{~h}$ was not significantly different from that at $12 \mathrm{~h}$. To assess cytotoxicity of NAC/NACA, the HepaRG cells were incubated for $24 \mathrm{~h}$ with different concentrations of NACA or NAC $(0.10,0.50,0.75,1.0,1.5,5.0$, and $10.0 \mathrm{mM}$ ). NACA was nontoxic below $1 \mathrm{mM}$; however, NAC induced toxicity in HepaRG cells above $0.75 \mathrm{mM}$ (Figure 1(c)).

\section{Protective effect of NAC/NACA on APAP-induced cytotoxicity}

To study the protective effects of NAC/NACA on APAPinduced toxicity, HepaRG cells were pretreated for $2 \mathrm{~h}$ with several concentrations of NAC or NACA, followed by incubation with $20 \mathrm{mM}$ of APAP for $24 \mathrm{~h}$. The cell viability was then measured using the Calcein AM Assay. There was a significant increase in the cell viability in the $250 \mu \mathrm{M}$ NAC or NACA pretreatment group (Figure 2(a)). Therefore, a $250 \mu \mathrm{M}$ nontoxic dose of NAC/NACA was chosen for subsequent experiments to study their protective effects on APAP-induced cytotoxity and oxidative stress. Furthermore, when protective effects of NAC were compared with those of NACA at $250 \mu \mathrm{M}$, we observed that NACA offered significantly better protection than NAC. In addition to the Calcein AM assay, cytotoxicity was assessed by the extent of $\mathrm{LDH}$ released in the culture medium after APAP treatment. LDH release increased significantly after APAP treatment (to $370 \%$ of the control) after $24 \mathrm{~h}$. NACA pretreatment significantly decreased it to $330 \%$ of the control (Figure 2(b)), whereas NAC did not decrease it significantly compared with the APAP treatment group.

\section{Protective effect of NAC/NACA on NAPQI-induced cytotoxicity}

To substantiate the hypothesis that NAPQI, a toxic metabolite, was involved in the hepatotoxicity induced by APAP, cell viability was measured after directly treating HepaRG cells with NAPQI for $24 \mathrm{~h}$. We chose $250 \mu \mathrm{M}$ of NAPQI, based on the dose-response study (Figure 3(a), which showed $40 \%$ cell death at this concentration, which was 

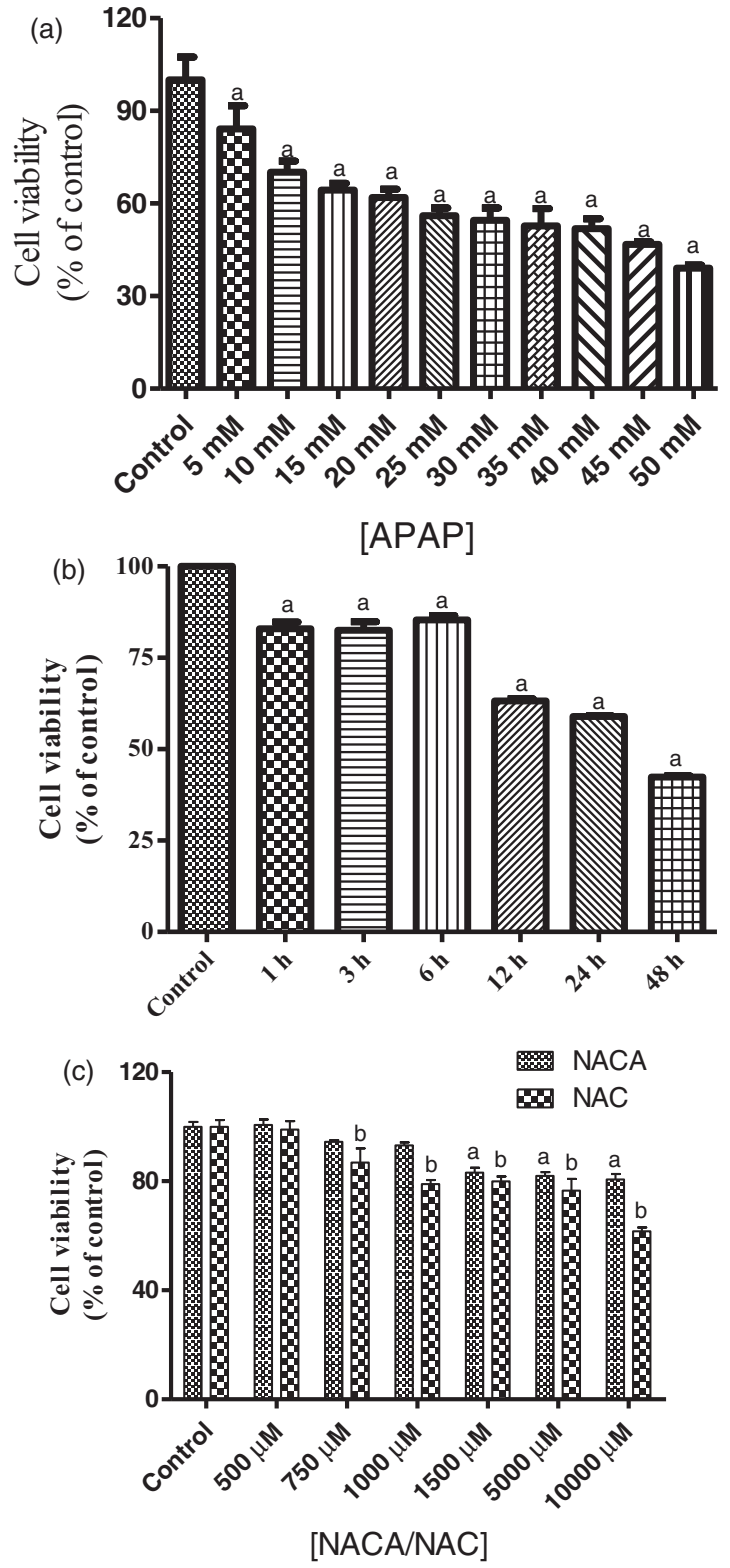

Figure 1 Cell viability of HepaRG cells. (a) Dose-response for APAP-induced cytotoxicity. (b) Time-response for APAP-induced cytotoxicity. (c) Cytotoxicity induced by NACA and NAC. Cell viability was quantified using Calcein AM assay. For dose-response studies, cell viability was measured after $24 \mathrm{~h}$ and timeresponse studies cells were treated with $20 \mathrm{mM}$ APAP. ${ }^{a} p \leq 0.05$ compared to the control group in Figure 1(a) and (b). ${ }^{a} p \leq 0.05$ compared to the control group for NACA and ${ }^{b} p \leq 0.05$ compared to the control group for NAC in Figure 1(c). The graph is representative of five replicates and the values reported are mean $\pm S D$

similar to $20 \mathrm{mM}$ APAP. NACA pretreatment significantly increased it to $73 \%$ of the control (Figure 3(b)). However, NAC pretreatment was not as effective at protecting cells against NAPQI-induced cytotoxicity.

\section{Effect of NAC/NACA on intracellular levels of GSH, GSSG, and the ratio of GSH/GSSG}

To further support our hypothesis that depletion of intracellular GSH is a crucial event in APAP-induced toxicity, we investigated its effect on GSH at $12 \mathrm{~h}$ (Figure $4(\mathrm{a})$ ) and $24 \mathrm{~h}$
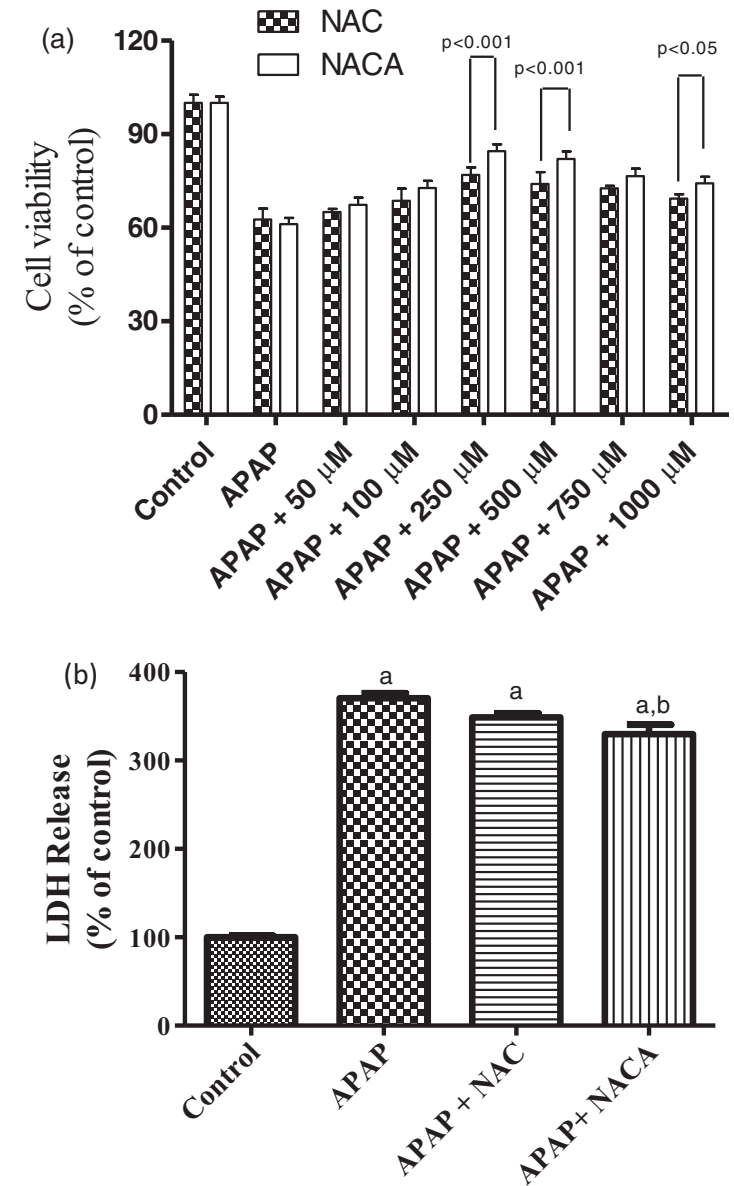

Figure 2 Protective effect of NAC/NACA in APAP-induced cytotoxicity. (a) Cell viability of HepaRG cells after pretreatment with NAC/NACA, followed by $20 \mathrm{mM}$ APAP for $24 \mathrm{~h}$. Cell viability was quantified by a Calcein AM assay. Treatment with APAP $(20 \mathrm{mM})$ alone was seen to significantly decrease cell viability. NAC/NACA $(250 \mu \mathrm{M})$ showed significant protection against APAP-induced cell toxicity $(p \leq 0.05)$ except for $50 \mu \mathrm{M}$ NAC pretreatment. NACA pretreated group showed better protection at three concentrations, as represented in the plot. (b) Effect of NAC/NACA on lactate dehydrogenase release in APAP treated cells. NACA pretreatment significantly decreased the release of LDH. ${ }^{a} p \leq 0.05$ compared to the control group, and ${ }^{\mathrm{b}} \mathrm{p} \leq 0.05$ compared to the APAP group. The graph is representative of five replicates and the values reported are mean \pm SD

(Figure $4(\mathrm{~b})$ ). GSH levels significantly decreased to $48 \%$ of the control after treatment with $20 \mathrm{mM}$ of APAP for $12 \mathrm{~h}$. No significant increase in the GSSG levels was observed after APAP treatment in HepaRG cells for $12 \mathrm{~h}$. However, the GSH/GSSG ratio, an important parameter of oxidative stress, decreased significantly in the $20 \mathrm{mM}$ of APAP treatment group after $12 \mathrm{~h}$. NACA pretreatment significantly increased the GSH level to $76 \%$ of the control in addition to increasing the ratio of GSH/GSSG to near control levels. Interestingly, $250 \mu \mathrm{M}$ of NAC pretreatment was not effective at increasing the level of GSH and the GSH/GSSG ratio significantly after $12 \mathrm{~h}$ of APAP treatment (Figure 4(a)). However, after $24 \mathrm{~h}$ of APAP treatment, both NAC and NACA were effective at increasing the GSH/GSSG ratio. Furthermore, NACA was significantly better than NAC at increasing intracellular GSH levels, decreasing the levels of GSSG and, thereby, increasing the ratio of GSH/GSSH after $24 \mathrm{~h}$. 

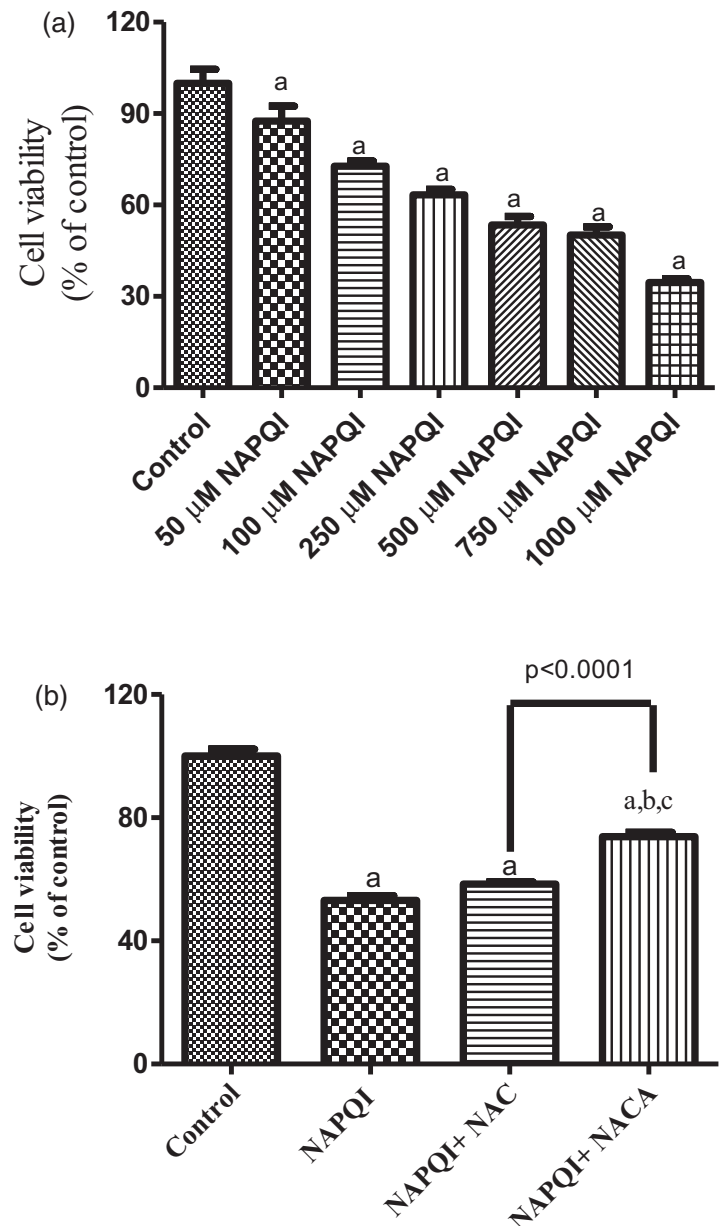

Figure 3 NAPQI-induced cytotoxicity in HepaRG cells. (a) Dose-response for NAPQI-induced cytotoxicity. (b) Protective effect of NAC/NACA in NAPQIinduced cytotoxicity. Cell viability was quantified by a Calcein AM assay after $24 \mathrm{~h}$. Cell viability was assessed after pretreating HepaRG cells with $250 \mu \mathrm{M}$ NAC/NACA followed by $250 \mu \mathrm{M}$ NAPQI for $24 \mathrm{~h}$. Treatment with NAPQI $(250 \mu \mathrm{M})$ alone was seen to significantly decrease cell viability. NACA protected against NAPQI-induced cell toxicity, whereas NAC did not show any protection. Values represent mean $\pm S D(n=4)$. $p<0.0001$ (a: different from control group, b: different from NAPQI group, and $c$ : different from $250 \mu \mathrm{M}$ NAC group)

\section{Protective effect of NAC/NACA on APAP-induced increase in intracellular ROS}

To elucidate the role of oxidative stress in APAP-induced toxicity, ROS levels were measured at several time points $(1,3,6,12$, and $24 \mathrm{~h})$ after treatment of HepaRG with $20 \mathrm{mM}$ APAP. A significant time-dependent increase in ROS was observed upon treatment with APAP (Figure 5(a)). However, pretreatment with $250 \mu \mathrm{M}$ NAC/NACA reduced it to near control levels (Figure 5(b)).

\section{Protective effect of NAC/NACA on lipid peroxidation}

MDA, an index of lipid peroxidation, was measured in HepaRG cells after treatment with APAP for $24 \mathrm{~h}$. Significantly higher levels (592\% of the control) of MDA were observed after $24 \mathrm{~h}$, but not after $12 \mathrm{~h}$ of treatment (Table 1). Pretreatment with $250 \mu \mathrm{M}$ of NAC and NACA significantly reduced this increase in MDA to 302 and
$263 \%$ of the control, respectively. Pretreatment with NACA $(p<0.05)$ was better than NAC $(p<0.0001)$ at decreasing lipid peroxidation, when compared to the control.

\section{Effect of NAC/NACA on activity of GR in HepaRG cells treated with APAP}

Although no significant change in GR activity was observed at $12 \mathrm{~h}$, it significantly reduced to $28 \%$ of the control after $24 \mathrm{~h}$ of APAP treatment. NAC and NACA pretreatment significantly restored the GR activity to 57 and $70 \%$ of the control, respectively (Table 1). NACA pretreatment was significantly better than NAC at restoring the activity of GR with $\mathrm{p}<0.0001$.

\section{Effect of NAC/NACA on mitochondrial membrane potential in HepaRG cells treated with APAP}

Mitochondrial dysfunction is a hallmark in APAPinduced hepatotoxicity. Disruptions in mitochondrial permeability and function were assessed by using the membrane-permeative potentiometric dye JC-1. This dye preferentially localizes to the mitochondria in healthy cells and forms aggregates which fluoresce red. However, in cells with mitochondrial dysfunction, where the mitochondrial membrane potential decreases, the dye diffuses into the cytoplasm and its monomeric form fluoresces green. As shown in Figure 6, control cells were stained both red and green, whereas a decrease in red fluorescence was seen in the APAP-treated group. Decrease in the red fluorescence in the APAP-treated group indicated that APAP treatment suppressed $\Psi \mathrm{m}$ in the HepaRG cells. However, NAC/NACA pretreatment restored the mitochondrial membrane potential, as evidenced by red fluorescence similar to that of the control. These results support our hypothesis that NACA pretreatment preserves mitochondrial function in a manner similar to that of NAC.

\section{Discussion}

An overdose of APAP is one of the leading causes of death in the U.S. and accounts for huge hospitalization costs every year. Although only a few different mechanisms have been proposed for APAP-induced toxicity, a significant amount of evidence has pointed to the potential involvement of oxidative stress in APAP toxicity. ${ }^{50-56}$ Depletion of GSH is one of the initiating steps in APAP-induced hepatotoxicity; ${ }^{57}$ therefore, one strategy for restricting organ damage is to restore GSH levels by using GSH prodrugs. Since, NAC, the only approved antidote for APAP toxicity, has poor bioavailability and requires higher doses and longer treatment times, we studied the protective effect of NACA, which has higher bioavailability on APAP-induced hepatotoxicity and its effects were compared with those of NAC. Herein, we report the in vitro effects of APAP on the HepaRG cell line and the role of NACA in preventing APAP-induced hepatotoxicity, and these findings were compared with those of NAC.

Results from our study show that HepaRG cells treated with APAP experienced a significant decrease in GSH levels 

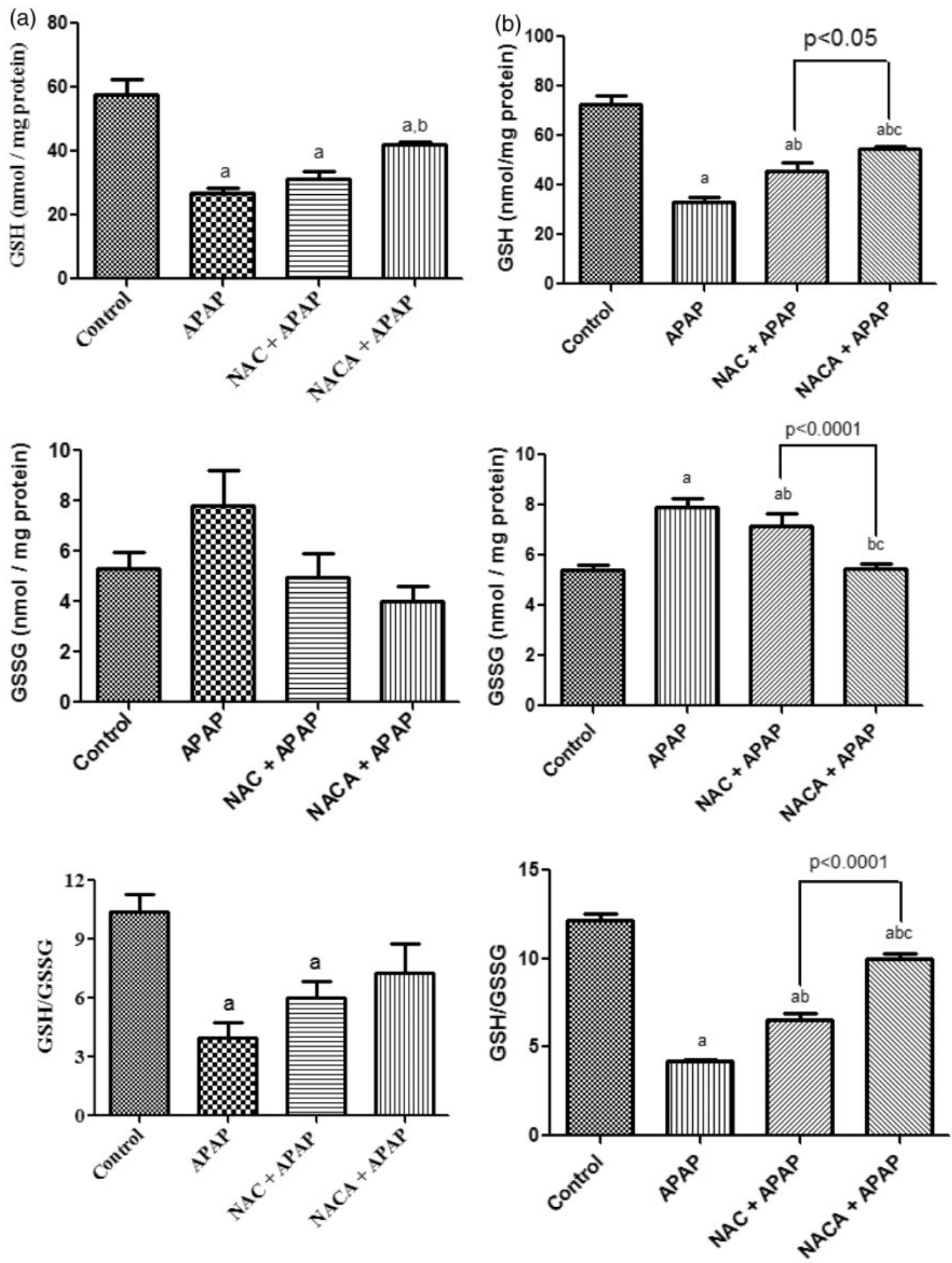

Figure 4 Intracellular levels of GSH, GSSG, and GSH/GSSG ratio in HepaRG cells after treatment with $20 \mathrm{mM}$ APAP (a) $12 \mathrm{~h}$ and (b) $24 \mathrm{~h}$. Pretreatment with NACA $(250 \mu \mathrm{M}), 2 \mathrm{~h}$ before the addition of APAP showed significantly better protection compared with NAC after $24 \mathrm{~h}$. Values represent mean \pm SD $(\mathrm{n}=4)(\mathrm{a}$ : different from the control group, b: different from the $20 \mathrm{mM}$ APAP group, and c: different from $250 \mu \mathrm{M} \mathrm{NAC} \mathrm{group).} \mathrm{p}<0.05$ for $12 \mathrm{~h}$ and $\mathrm{p}<0.0001$ for $24 \mathrm{~h}$

and cell viability, indicating that the increase in oxidative stress (which was due to the decrease in GSH levels) was responsible for reduced cell viability. A significant decrease in GSH levels after APAP treatment could be due to conjugation with NAPQI during the detoxification pathway. ${ }^{57}$ Our results are in line with previous studies that reported a decrease in GSH levels upon APAP treatment in animal models and in cell cultures. ${ }^{56,58,59,60-65}$ However, the time and amplitude of decreases varied with cell lines and the animal models used for these studies. In addition to a decrease in GSH, increases in intracellular GSSG have been reported during the recovery phase of cellular GSH content $^{50,66}$ after APAP treatment. Although, we did not see a significant increase in GSSG after $12 \mathrm{~h}$ of APAP treatment, we did see a significant increase in GSSG levels after $24 \mathrm{~h}$ of treatment with $20 \mathrm{mM}$ APAP. Decreases in GSH with concomitant increases in GSSG, after APAP treatment, have been reported by Zhao et al. ${ }^{67}$ Furthermore, the ratio of GSH/GSSG, which serves as a representative marker of the antioxidative capacity of a cell, decreased by about 2.6 - and 2.9-fold, respectively, after 12 and $24 \mathrm{~h}$ of APAP treatment. Our results are in accordance with a previous study that reported a similar decrease in the GSH/GSSG ratio after $24 \mathrm{~h}$ of APAP treatment. ${ }^{68}$ 

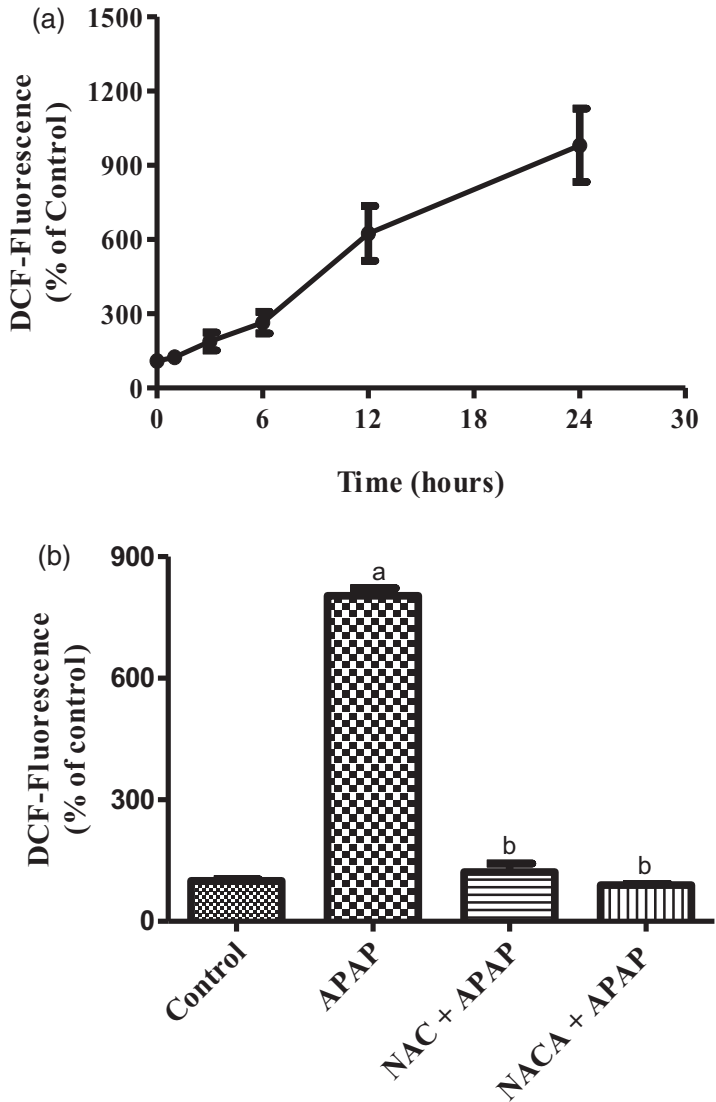

Figure 5 ROS levels in HepaRG cells. (a) Time-response for APAP-induced generation of ROS after treatment with $20 \mathrm{mM}$ APAP; (b) ROS levels after treatment with $20 \mathrm{mM}$ APAP and $250 \mu \mathrm{M}$ NAC/NACA pretreatment. ROS levels were measured after $12 \mathrm{~h}$ of treatment for control, NAC/NACA, APAP, and APAP + NAC/NACA groups. $20 \mathrm{mM}$ of APAP significantly increased the ROS level. Pretreatment with $250 \mu \mathrm{M}$ of NAC/NACA returned the ROS level to near that of the control level. Values represent mean $\pm S D(n=5)$. $p<0.0001$ (a: different from the control group and b: different from the $20 \mathrm{mM}$ APAP group)

Table 1 MDA levels and GR activity in HepaRG cells

\begin{tabular}{lcl}
\hline Group & $\begin{array}{l}\text { TBARS } \\
\text { (nmol MDA/mg protein) }\end{array}$ & $\begin{array}{l}\text { GR } \\
\text { (mU/mg protein) }\end{array}$ \\
\hline Control & $21.61 \pm 0.80$ & $86.22 \pm 1.39$ \\
APAP-only & $127.8 \pm 9.95^{\mathrm{a}}$ & $24.44 \pm 1.91^{\mathrm{a}}$ \\
APAP + NAC & $65.29 \pm 8.43^{\mathrm{a}, \mathrm{b}}$ & $49.31 \pm 2.29^{\mathrm{a}, \mathrm{b}}$ \\
APAP + NACA & $56.80 \pm 2.71^{\mathrm{a} 1, \mathrm{~b}}$ & $60.03 \pm 2.38^{\mathrm{a}, \mathrm{b}, \mathrm{c}}$ \\
\hline
\end{tabular}

The oxidative stress parameters in the NAC/NACA-only group were very similar to those of the control group, whereas the APAP-only group had elevated oxidative stress parameters for each of the indicators listed.

${ }^{a} p<0.0001$ in comparison with the control group; ${ }^{a 1} p<0.05$ in comparison with control group.

${ }^{b} p<0.0001$ in comparison with the APAP-only group.

${ }^{c} p<0.0001$ in comparison with the NAC group.

APAP treatment significantly reduced cell viability in a concentration- and time-dependent manner. Our results are in agreement with previous studies that reported reduced cell viability after APAP treatment. ${ }^{59,67}$ To substantiate our hypothesis, that NAPQI formation is the main event in
APAP-induced toxicity, we examined the effect of NAPQI exposure on cell viability. Exposure to NAPQI decreased cell viability in a dose-dependent fashion as well.

However, pretreatment with NACA significantly increased cell viability in the APAP/NAPQI-treated group (Figure 2) as well as the GSH levels (Figure 4) in the APAP treated group. This indicated that NACA had replenished the GSH levels in these cells and prevented oxidative stressinduced cell death. Although NAC was effective at increasing GSH levels, NACA was significantly better than NAC at increasing the GSH levels and the GSH/GSSG ratio, as well as cell viability after $24 \mathrm{~h}$ of treatment with APAP. This could be attributed to the lower bioavailability of NAC when compared with NACA.

The protective effects of NACA are probably mediated by its ability to supply cysteine for GSH biosynthesis, in addition to reducing extracellular cystine to cysteine, by conversion of GSSG to GSH by nonenzymatic thiol disulfide exchange, and by restoring GR activity. ${ }^{34,69}$ Despite being strong sulfhydryl nucleophiles, NAC/NACA are poor targets for NAPQI possibly due to their high $\mathrm{pKa}$ ( 9.6 for NAC) at physiological $\mathrm{pH}$, which prevents the cysteine sulfhydryl group from converting into reactive anionic state. Studies have demonstrated that the protection of NAC against APAP overdose requires the synthesis of GSH. Indeed, previous research has suggested that NAC does not scavenge NAPQI and, therefore, cannot protect against the initial phase of toxicity. Rather, NAC hepatoprotection might involve an alternative mechanism that impacts the toxic phase, e.g. free radical trapping, increased GSH synthesis, or enhanced mitochondrial energy production. ${ }^{70-73}$

Further, depletion of GSH may lead to increased ROS in the cells. A significant, time-dependent increase in total ROS was observed in our study (Figure 5(a)). Our data are in agreement with other studies that have reported an increase in the production of ROS upon APAP treatment. ${ }^{56,62}$ In addition, Bajt et al. ${ }^{56}$ showed that ROS was produced as a consequence of decreased GSH levels. However, pretreatment with NAC/NACA significantly decreased the ROS (Figure 5(b)).

A decrease in GSH and an increase in ROS set off a cascade of further oxidative damage. ROS are capable of causing oxidative damage to all major macromolecules in cells, including lipids, proteins, and nucleic acids. Oxidized derivatives of these substrates were studied as markers of oxidative stress. Polyunsaturated fatty acids, major components of cell membranes, can undergo free radical attack and produce lipid peroxidation products that are frequently used to quantify oxidative stress-related injury. Levels of MDA, a lipid peroxidation by-product, provided a suitable index for measurement of lipid peroxidation in vivo. In accordance with previous studies, ${ }^{60,62,65,68,74-76}$ we observed increased levels of MDA after $24 \mathrm{~h}$ of APAP treatment. In general, once toxic lipid peroxides are formed by free radicals, GPx attempts to eliminate them at the expense of GSH. Unavailability of GSH as a substrate for GPx might have stalled the process of lipid peroxide decomposition, thereby building up the levels of MDA. However, pretreatment with NAC/NACA was able to break the lipid 


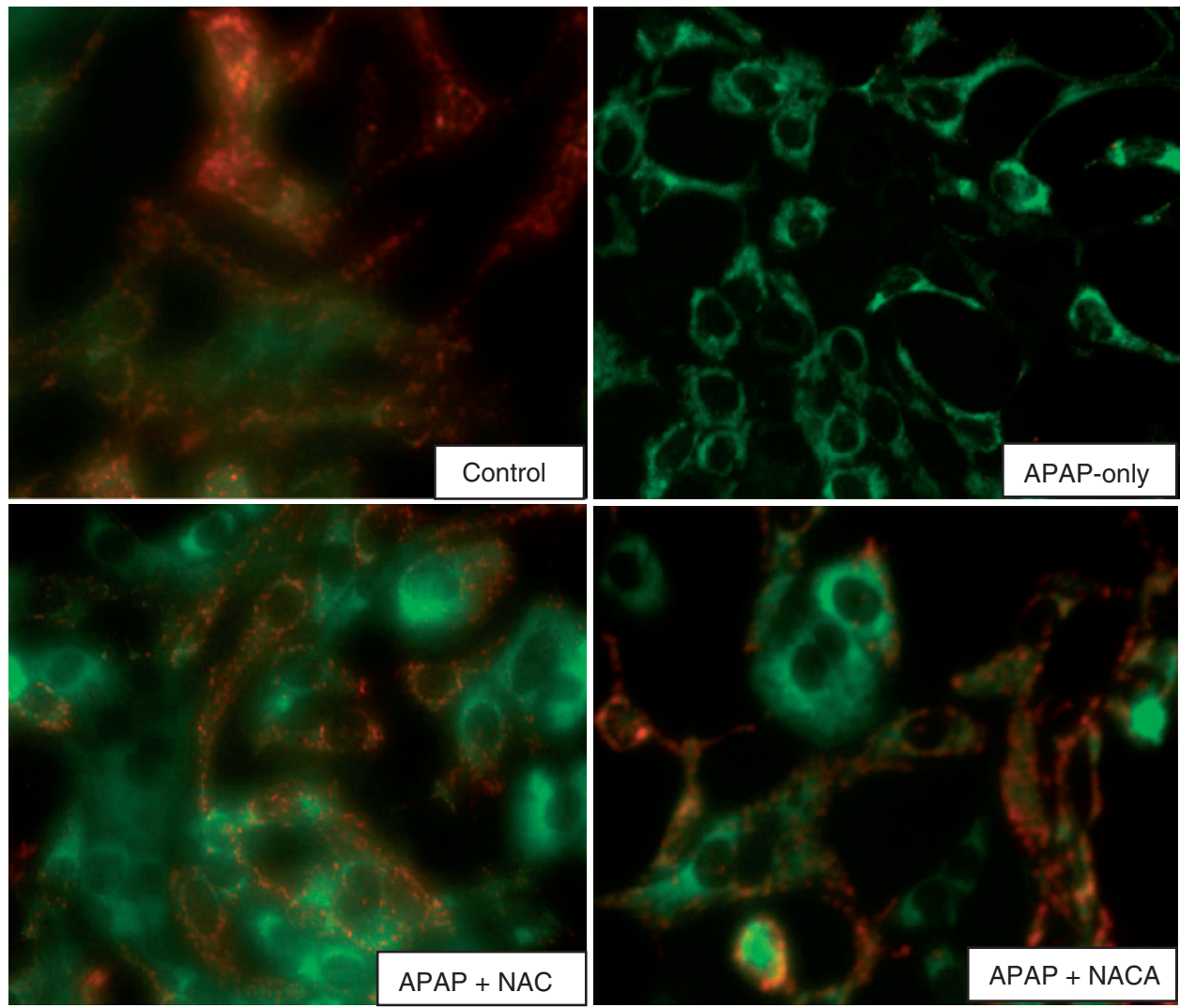

Figure 6 Analysis of mitochondrial membrane potential $(\Delta \Psi \mathrm{m}) . \Delta \Psi \mathrm{m}$ was analyzed in the HepaRG cells after $24 \mathrm{~h}$ of APAP treatment, using the potential-dependent aggregate forming lipophilic cation JC-1. Mitochondria exhibited red fluorescence when $\triangle \Psi \mathrm{m}$ was preserved. Mitochondria in APAP-treated cells showed a decrease in red fluorescence due to loss of $\Delta \Psi \mathrm{m}$. However, pretreatment with NAC/NACA preserved $\Delta \Psi \mathrm{m}$, as seen by red fluorescence similar to that of the control group. (A color version of this figure is available in the online journal.)

peroxidation chain reaction by supplying an adequate amount of GSH, as a substrate for GPx, to effectively decompose lipid peroxides, thus reducing MDA levels.

GR is a key antioxidant enzyme involved in the maintenance of cellular GSH homeostasis. It reduces GSSG back to the reduced form, GSH. A significant reduction in the activity of GR was observed upon APAP treatment. Decreased antioxidant enzyme activity upon APAP treatment has been reported in literature. ${ }^{77}$ Decrease in GR activity, with time, has been reported in rat hepatocytes treated with $20 \mathrm{mM}$ APAP. Some studies have indicated that loss of GSH will directly affect the activity of the GSH-dependent enzyme GR. Loss of protein sulfhydryl (protein-SH) groups, which are believed to be essential for enzyme activity under oxidative stress, has been previously reported. ${ }^{78,79}$ In addition, NAPQI is reported to cause loss in protein thiol groups. ${ }^{80}$ Reduced activity of GR could also be attributed to a decrease in NADPH, a cofactor for GR, since NAPQI is reported to undergo rapid reduction to APAP using NADPH.${ }^{81}$ Under such circumstances, GSH is not regenerated, thus, leading to further oxidative stress. Decreased activity of GR seen in our experiments upon APAP treatment supports our hypothesis of GSH depletion as a key event in APAP-induced hepatotoxicity. Our results are in accordance with Al-Belooshi et al. ${ }^{.2}$ who reported a decrease in mitochondrial GR after APAP treatment.
Pretreatment with NACA increased the GR activity by $40 \%$, which could have been due to regeneration of protein sulfhydryl groups by a nonenzymatic thiol-disulfide exchange. NACA was significantly better than NAC $(\mathrm{p}<0.0001)$ at restoring GR activity.

Mitochondrial dysfunction is one of the key events in APAP-induced cell death. The MPT is recognized as an initiating phenomenon in APAP-induced toxicity. A decrease in the $\triangle \Psi \mathrm{m}$ after APAP treatment was detected using fluorescence microscopy, which is consistent with disrupted mitochondrial function (Figure 6). However, NAC/NACA pretreatment restored the mitochondrial membrane potential, as evidenced by a red fluorescence similar to that of the control. Studies by Nazareth et al..$^{82}$ showed a similar decrease in mitochondrial membrane potential after APAP treatment.

In summary, our data indicate that an APAP overdose causes oxidative stress and mitochondrial dysfunction in HepaRG cells. APAP-induced cell death in HepaRG cells could be due to depletion of GSH by NAPQI, which results in the formation of NAPQI-protein adduct and increased oxidative stress that leads to the loss of the mitochondrial membrane potential and, ultimately, cell death. Therefore, we conclude that NACA protects by synthesizing GSH which conjugates with NAPQI and prevents its subsequent binding to mitochondrial proteins and the resulting 
dysfunction. In addition, it protects by scavenging ROS and subsequent oxidative damage to macromolecules. These results suggested that NACA was significantly better than NAC at alleviating APAP-induced oxidative stress.

Thus, NACA, a GSH prodrug with radical scavenging and antioxidant properties, appears to be a better therapeutic agent for treating APAP-induced toxicity and may require lower doses and treatment times. Based on these encouraging in vitro results, our future studies will focus on studying the protective effects of NACA in animal models. Further investigations will help determine NACA's efficacy in APAP-induced toxicities and an evaluation of the histology of livers in APAP-treated animals will provide additional information on NACA's therapeutic potential.

\section{AUTHORS' CONTRIBUTIONS}

ST and AK are co-first authors and have contributed equally to the work being described. AK designed and conducted most of the experiment. WF conducted some experiments. ST designed, analyzed, and wrote the manuscript. NE designed, reviewed, and finalized the manuscript.

\section{ACKNOWLEDGEMENTS}

The authors appreciate the efforts of Barbara Harris in editing the manuscript.

\section{CONFLICT OF INTEREST}

The authors have no financial, consulting, or personal conflicts of interest pertaining to this work. Dr Ercal is supported by Richard K. Vitek endowment.

\section{REFERENCES}

1. Lee WM. Acetaminophen and the U.S. Acute Liver Failure Study Group: Lowering the risks of hepatic failure. Hepatology 2004;40:6-9

2. Larson AM, Polson J, Fontana RJ, Davern TJ, Lalani E, Hynan LS, Reisch JS, Schiødt FV, Ostapowicz G, Shakil AO, Lee WM. Acetaminophen-induced acute liver failure: Results of a United States multicenter, prospective study. Hepatology 2005;42:1364-72

3. Schiodt FV, Atillasoy E, Shakil AO, Schiff ER, Caldwell C, Kowdley KV, Stribling R, Crippin JS, Flamm S, Somberg KA, Rosen H, McCashland TM, Hay JE, Lee WM. Etiology and outcome for 295 patients with acute liver failure in the United States. Liver Transpl Surg 1999;5:29-34

4. Lee WM. Drug-induced hepatotoxicity. N Engl J Med 2003;349:474-85

5. Nourjah P, Ahmad SR, Karwoski C, Willy M. Estimates of acetaminophen (Paracetomal)-associated overdoses in the United States. Pharmacoepidemiol Drug Saf 2006;15:398-405

6. Budnitz DS, Lovegrove MC, Crosby AE. Emergency department visits for overdoses of acetaminophen-containing products. Am J Prev Med 2011;40:585-92

7. Nelson SD. Molecular mechanisms of the hepatotoxicity caused by acetaminophen. Semin Liver Dis 1990;10:267-78

8. McGill MR, Sharpe MR, Williams CD, Taha M, Curry SC, Jaeschke H The mechanism underlying acetaminophen-induced hepatotoxicity in humans and mice involves mitochondrial damage and nuclear DNA fragmentation. J Clin Invest 2012;122:1574-83

9. Dahlin DC, Nelson SD. Synthesis, decomposition kinetics, and preliminary toxicological studies of pure N-acetyl-p-benzoquinone imine, a proposed toxic metabolite of acetaminophen. J Med Chem 1982;25:885-6
10. Chen C, Hennig GE, Manautou JE. Hepatobiliary excretion of acetaminophen glutathione conjugate and its derivatives in transport-deficient (TR-) hyperbilirubinemic rats. Drug Metab Dispos 2003;31:798-804

11. Mitchell JR, Jollow DJ, Potter WZ, Davis DC, Gillette JR, Brodie BB. Acetaminophen-induced hepatic necrosis. I. Role of drug metabolism. J Pharmacol Exp Ther 1973;187:185

12. McGill MR, Lebofsky M, Norris HR, Slawson MH, Bajt ML, Xie Y, Williams CD, Wilkins DG, Rollins DE, Jaeschke H. Plasma and liver acetaminophen-protein adduct levels in mice after acetaminophen treatment: Dose-response, mechanisms, and clinical implications. Toxicol Appl Pharmacol 2013;269:240-9

13. Coles B, Wilson I, Wardman P, Hinson JA, Nelson SD, Ketterer B. The spontaneous and enzymatic reaction of N-acetyl-p-benzoquinonimine with glutathione: A stopped-flow kinetic study. Arch Biochem Biophys 1988;264:253-60

14. Potter WZ, Davis DC, Mitchell JR, Jollow DJ, Gillette JR, Brodie BB. Acetaminophen-induced hepatic necrosis. 3. Cytochrome P-450mediated covalent binding in vitro. J Pharmacol Exp Ther 1973;187:203-10

15. Tirmenstein MA, Nelson SD. Subcellular binding and effects on calcium homeostasis produced by acetaminophen and a nonhepatotoxic regioisomer, 3'-hydroxyacetanilide, in mouse liver. J Biol Chem 1989;264:9814-9

16. Cohen SD, Pumford NR, Khairallah EA, Boekelheide K, Pohl LR, Amouzadeh HR, Hinson JA. Selective protein covalent binding and target organ toxicity. Toxicol Appl Pharmacol 1997;143:1-12

17. Jaeschke H, Bajt ML. Intracellular signaling mechanisms of acetaminophen-induced liver cell death. Toxicol Sci 2006;89:31-41

18. Kon K, Kim JS, Jaeschke H, Lemasters JJ. Mitochondrial permeability transition in acetaminophen-induced necrosis and apoptosis of cultured mouse hepatocytes. Hepatology 2004;40:1170-9

19. Masubuchi $Y$, Suda C, Horie T. Involvement of mitochondrial permeability transition in acetaminophen-induced liver injury in mice. J Hepatol 2005;42:110-6

20. Ramachandran A, Lebofsky M, Baines CP, Lemasters JJ, Jaeschke H. Cyclophilin D deficiency protects against acetaminophen-induced oxidant stress and liver injury. Free Radic Res 2011;45:156-64

21. Burcham PC, Harman AW. Acetaminophen toxicity results in sitespecific mitochondrial damage in isolated mouse hepatocytes. J Biol Chem 1991;266:5049-54

22. Dai Y, Cederbaum AI. Cytotoxicity of acetaminophen in human cytochrome P4502E1-transfected HepG2 cells. J Pharmacol Exp Ther 1995;273:1497-505

23. Jaeschke H, Williams CD, Ramachandran A, Bajt ML. Acetaminophen hepatotoxicity and repair: The role of sterile inflammation and innate immunity. Liver Int 2012;32:8-20

24. Bantel H, Schulze-Osthoff K. Mechanisms of cell death in acute liver failure. Front Physiol 2012;3:79

25. Polson J, Lee WM. AASLD position paper: the management of acute liver failure. Hepatology 2005;41:1179-97

26. Prescott LF, Park J, Ballantyne A, Adriaenssens P, Proudfoot AT. Treatment of paracetamol (acetaminophen) poisoning with Nacetylcysteine. Lancet 1977;2:432-4

27. Yarema MC, Johnson DW, Berlin RJ, Sivilotti ML, Nettel-Aguirre A, Brant RF, Spyker DA, Bailey B, Chalut D, Lee JS, Plint AC, Purssell RA, Rutledge T, Seviour CA, Stiell IG, Thompson M, Tyberg J, Dart RC, Rumack BH. Comparison of the 20-hour intravenous and 72-hour oral acetylcysteine protocols for the treatment of acute acetaminophen poisoning. Ann Emerg Med 2009;54:606-14

28. Millea PJ. N-acetylcysteine: multiple clinical applications. Am Fam Physician 2009;80:265-9

29. Parasassi T, Brunelli R, Costa G, De Spirito M, Krasnowska E, Lundeberg T, Pittaluga E, Ursini F. Thiol redox transitions in cell signaling: A lesson from N-acetylcysteine. Sci World J 2010;10:1192-202

30. Saito C, Zwingmann C, Jaeschke H. Novel mechanisms of protection against acetaminophen hepatotoxicity in mice by glutathione and N-acetylcysteine. Hepatology 2010;51:246-54

31. Tobwala S, Zhang X, Zheng Y, Wang HJ, Banks WA, Ercal N. Disruption of the integrity and function of brain microvascular endothelial cells in 
culture by exposure to diesel engine exhaust particles. Toxicol Lett 2013;220:1-7

32. Banerjee A, Trueblood MB, Zhang X, Manda KR, Lobo P, Whitefield PD, Hagen DE, Ercal N. N-acetylcysteineamide (NACA) prevents inflammation and oxidative stress in animals exposed to diesel engine exhaust. Toxicol Lett 2009;187:187-93

33. Carey JW, Pinarci EY, Penugonda S, Karacal H, Ercal N. In vivo inhibition of 1-buthionine-(S,R)-sulfoximine-induced cataracts by a novel antioxidant, N-acetylcysteine amide. Free Radic Biol Med 2011;50:722-9

34. Grinberg L, Fibach E, Amer J, Atlas D. N-acetylcysteine amide, a novel cell-permeating thiol, restores cellular glutathione and protects human red blood cells from oxidative stress. Free Radic Biol Med 2005;38:136-45

35. Offen D, Gilgun-Sherki Y, Barhum Y, Benhar M, Grinberg L, Reich R, Melamed E, Atlas D. A low molecular weight copper chelator crosses the blood-brain barrier and attenuates experimental autoimmune encephalomyelitis. J Neurochem 2004;89:1241-51

36. Penugonda S, Ercal N. Comparative evaluation of $\mathrm{N}$-acetylcysteine (NAC) and N-acetylcysteine amide (NACA) on glutamate and leadinduced toxicity in CD-1 mice. Toxicol Lett 2011;201:1-7

37. Carey JW, Tobwala S, Zhang X, Banerjee A, Ercal N, Pinarci E, Karacal H. N-Acetyl L-cysteine amide protects retinal pigment epithelium against methamphetamine-induced oxidative stress. J Biophys Chem 2012;3:101-10

38. Tobwala S, Fan W, Stoeger T, Ercal N. N-acetylcysteine amide, a thiol antioxidant, prevents bleomycin-induced toxicity in human alveolar basal epithelial cells (A549). Free Radic Res 2013;47:740-9

39. Zhang X, Banerjee A, Banks WA, Ercal N. N-Acetylcysteine amide protects against methamphetamine-induced oxidative stress and neurotoxicity in immortalized human brain endothelial cells. Brain Res 2009;1275:87-95

40. Zhang X, Tobwala S, Ercal N. N-acetylcysteine amide protects against methamphetamine-induced tissue damage in CD-1 mice. Hum Exp Toxicol 2012;31:931-44

41. Kanter MZ. Comparison of oral and i.v. acetylcysteine in the treatment of acetaminophen poisoning. Am J Health Syst Pharm 2006;63:1821-7

42. Heard KJ. Acetylcysteine for acetaminophen poisoning. N Engl J Med 2008;359:285-92

43. Aninat C, Piton A, Glaise D, Le Charpentier T, Langouet S, Morel F, Guguen-Guillouzo C, Guillouzo A. Expression of cytochromes P450, conjugating enzymes and nuclear receptors in human hepatoma HepaRG cells. Drug Metab Dispos 2006;34:75-83

44. Guillouzo A, Corlu A, Aninat C, Glaise D, Morel F, GuguenGuillouzo C. The human hepatoma HepaRG cells: A highly differentiated model for studies of liver metabolism and toxicity of xenobiotics. Chem Biol Interact 2007;168:66-73

45. Roe AL, Snawder JE, Benson RW, Roberts DW, Casciano DA. HepG2 cells: An in vitro model for P450-dependent metabolism of acetaminophen. Biochem Biophys Res Commun 1993;190:15-9

46. Winters RA, Zukowski J, Ercal N, Matthews RH, Spitz DR. Analysis of glutathione, glutathione disulfide, cysteine, homocysteine, and other biological thiols by high-performance liquid chromatography following derivatization by n-(1-pyrenyl)maleimide. Anal Biochem 1995;227:14-21

47. Wang H, Joseph JA. Quantifying cellular oxidative stress by dichlorofluorescein assay using microplate reader. Free Radic Biol Med 1999;27:612-6

48. Shi R, Huang CC, Aronstam RS, Ercal N, Martin A, Huang YW. $\mathrm{N}$-acetylcysteine amide decreases oxidative stress but not cell death induced by doxorubicin in H9c2 cardiomyocytes. BMC Pharmacol 2009;9:7

49. Bradford MM. A rapid and sensitive method for the quantitation of microgram quantities of protein utilizing the principle of protein-dye binding. Anal Biochem 1976;72:248-54

50. Jaeschke H. Glutathione disulfide formation and oxidant stress during acetaminophen-induced hepatotoxicity in mice in vivo: The protective effect of allopurinol. J Pharmacol Exp Ther 1990;255:935-41

51. Cover C, Mansouri A, Knight TR, Bajt ML, Lemasters JJ, Pessayre D, Jaeschke H. Peroxynitrite-induced mitochondrial and endonuclease- mediated nuclear DNA damage in acetaminophen hepatotoxicity. J Pharmacol Exp Ther 2005;315:879-87

52. Agarwal R, MacMillan-Crow LA, Rafferty TM, Saba H, Roberts DW, Fifer EK, James LP, Hinson JA. Acetaminophen-induced hepatotoxicity in mice occurs with inhibition of activity and nitration of mitochondrial manganese superoxide dismutase. J Pharmacol Exp Ther 2011;337:110-6

53. Andersson BS, Rundgren M, Nelson SD, Harder S. N-acetyl-p-benzoquinone imine-induced changes in the energy metabolism in hepatocytes. Chem Biol Interact 1990;75:201-11

54. Wendel A, Feuerstein S, Konz KH. Acute paracetamol intoxication of starved mice leads to lipid peroxidation in vivo. Biochem Pharmacol 1979;28:2051-5

55. Hinson JA, Michael SL, Ault SG, Pumford NR. Western blot analysis for nitrotyrosine protein adducts in livers of saline-treated and acetaminophen-treated mice. Toxicol Sci 2000;53:467-73

56. Bajt ML, Knight TR, Lemasters JJ, Jaeschke H. Acetaminophen-induced oxidant stress and cell injury in cultured mouse hepatocytes: protection by $\mathrm{N}$-acetyl cysteine. Toxicol Sci 2004;80:343-9

57. Mitchell JR, Jollow DJ, Potter WZ, Gillette JR, Brodie BB. Acetaminophen-induced hepatic necrosis. IV. Protective role of glutathione. J Pharmacol Exp Ther 1973;187:211-7

58. Choi J, Park KH, Kim SZ, Shin JH, Jang SI. The ameliorative effects of L-2-oxothiazolidine-4-carboxylate on acetaminophen-induced hepatotoxicity in mice. Molecules 2013;18:3467-78

59. McGill MR, Yan HM, Ramachandran A, Murray GJ, Rollins DE, Jaeschke H. HepaRG cells: A human model to study mechanisms of acetaminophen hepatotoxicity. Hepatology 2011;53:974-82

60. Fakurazi S, Sharifudin SA, Arulselvan P. Moringa oleifera hydroethanolic extracts effectively alleviate acetaminophen-induced hepatotoxicity in experimental rats through their antioxidant nature. Molecules 2012;17:8334-50

61. Tirmenstein MA, Nelson SD. Subcellular binding and effects on calcium homeostasis produced by acetaminophen and a nonhepatotoxic regioisomer, 3'-hydroxyacetanilide, in mouse liver. J Biol Chem 1989;264:9814-9

62. Al-Belooshi T, John A, Al-Otaiba A, Raza H. Acetaminophen-induced mitochondrial oxidative stress in murine J774.2 monocyte macrophages. Am J Biomed Sci 2010;2:142-54

63. Su GL, Gong KQ, Fan MH, Kelley WM, Hsieh J, Sun JM, Hemmila MR, Arbabi S, Remick DG, Wang SC. Lipopolysaccharide-binding protein modulates acetaminophen-induced liver injury in mice. Hepatology 2005;41:187-95

64. Burcham PC, Harman AW. Acetaminophen toxicity results in site-specific mitochondrial damage in isolated mouse hepatocytes. J Biol Chem 1991;266:5049-54

65. Fouad AA, Al-Mulhim AS, Jresat I, Gomaa W. Therapeutic role of telmisartan against acetaminophen hepatotoxicity in mice. Eur J Pharmacol 2012;693:64-71

66. Knight TR, Kurtz A, Bajt ML, Hinson JA, Jaeschke H. Vascular and hepatocellular peroxynitrite formation during acetaminophen toxicity: role of mitochondrial oxidant stress. Toxicol Sci 2001;62:212-20

67. Zhao X, Cong X, Zheng L, Xu L, Yin L, Peng J. Dioscin, a natural steroid saponin, shows remarkable protective effect against acetaminopheninduced liver damage in vitro and in vivo. Toxicol Lett 2012;214:69-80

68. Kumari A, Kakkar P. Lupeol prevents acetaminophen-induced in vivo hepatotoxicity by altering the $\mathrm{Bax} / \mathrm{Bcl}-2$ and oxidative stress-mediated mitochondrial signaling cascade. Life Sci 2012;90:561-70

69. Issels RD, Nagele A, Eckert KG, Wilmanns W. Promotion of cystine uptake and its utilization for glutathione biosynthesis induced by cysteamine and N-acetylcysteine. Biochem Pharmacol 1988;37:881-8

70. Corcoran GB, Racz WJ, Smith CV, Mitchell JR. Effects of N-acetylcysteine on acetaminophen covalent binding and hepatic necrosis in mice. J Pharmacol Exp Ther 1985;232:864-72

71. Corcoran GB, Wong BK. Role of glutathione in prevention of acetaminophen-induced hepatotoxicity by N-acetyl-L-cysteine in vivo: studies with N-acetyl-D-cysteine in mice. J Pharmacol Exp Ther 1986;238:54-61

72. Lauterburg BH, Corcoran GB, Mitchell JR. Mechanism of action of $\mathrm{N}$-acetylcysteine in the protection against the hepatotoxicity of acetaminophen in rats in vivo. J Clin Invest 1983;71:980-91 
73. Zwingmann C, Bilodeau M. Metabolic insights into the hepatoprotective role of $\mathrm{N}$-acetylcysteine in mouse liver. Hepatology 2006;43:454-63

74. Colle D, Arantes LP, Gubert P, da Luz SC, Athayde ML, Teixeira Rocha JB, Soares FA. Antioxidant properties of Taraxacum officinale leaf extract are involved in the protective effect against hepatoxicity induced by acetaminophen in mice. J Med Food 2012;15:549-56

75. Fakurazi S, Hairuszah I, Nanthini U. Moringa oleifera Lam prevents acetaminophen induced liver injury through restoration of glutathione level. Food Chem Toxicol 2008;46:2611-5

76. Uma N Jr, Fakurazi S, Hairuszah I. Moringa oleifera enhances liver antioxidant status via elevation of antioxidant enzymes activity and counteracts paracetamol-induced hepatotoxicity. Malays J Nutr 2010;16:293-307

77. He M, Zhang S, Jiao Y, Lin X, Huang J, Chen C, Chen Z, Huang R. Effects and mechanisms of rifampin on hepatotoxicity of acetaminophen in mice. Food Chem Toxicol 2012;50:3142-9
78. Agarwal R, Shukla GS. Potential role of cerebral glutathione in the maintenance of blood-brain barrier integrity in rat. Neurochem Res 1999;24:1507-14

79. Wu G, Fang YZ, Yang S, Lupton JR, Turner ND. Glutathione metabolism and its implications for health. J Nutr 2004;134:489-92

80. Albano E, Rundgren M, Harvison PJ, Nelson SD, Moldeus P. Mechanisms of N-acetyl-p-benzoquinone imine cytotoxicity. Mol Pharmacol 1985;28:306-11

81. Dahlin DC, Miwa GT, Lu AY, Nelson SD. N-acetyl-p-benzoquinone imine: a cytochrome P-450-mediated oxidation product of acetaminophen. Proc Natl Acad Sci USA 1984;81:1327-31

82. Nazareth WM, Sethi JK, McLean AE. Effect of paracetamol on mitochondrial membrane function in rat liver slices. Biochem Pharmacol 1991;42:931-6

(Received March 21, 2014, Accepted August 1, 2014) 